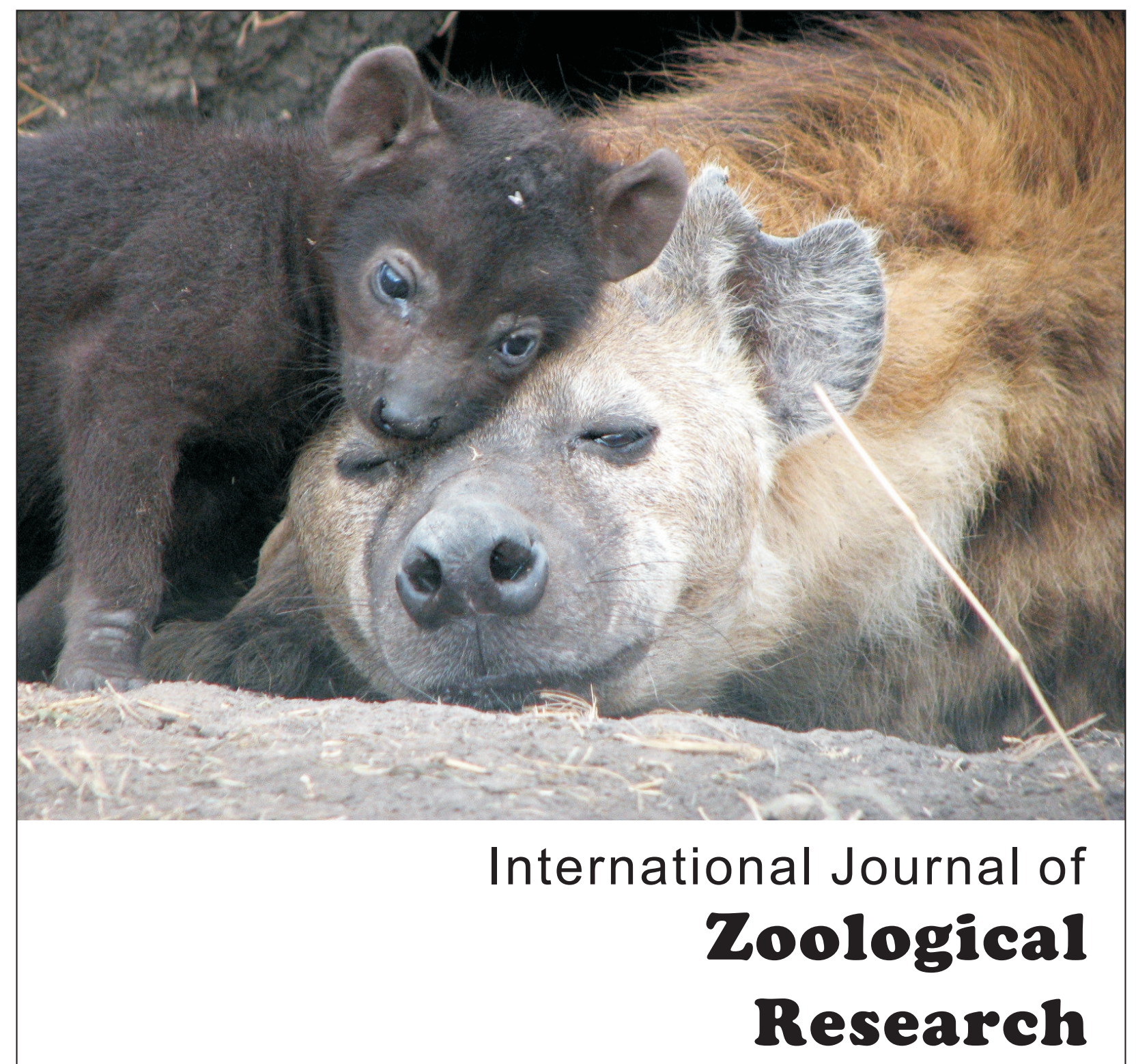

ISSN 1811-9778

\title{
(a)
}

Academic

Journals Inc. 


\title{
Research Article
}

\section{Genetic Variation of Limnonectes blythii (Anura: Dicroglossidae) Using RAPD (Random Amplified Polymorphic DNA) Analysis in West Sumatra}

\author{
Wince Hendri, Djong Hon Tjong, Dahelmi and Dewi Imelda Roesma
}

Department of Biology, Faculty of Mathematics and Natural Sciences, Andalas University, Kampus Unand Limau Manis Padang 25163 West Sumatra, Indonesia

\section{Abstract}

Background and Objective: Limnonectes blythii population in west Sumatra sharply decline because of its trading activity and damaged habitat. Conservation effort is necessary to protect the species. One of important information that needs to be done is to understand the species genetic variation. The aim of this study was to analyze the genetic variety of Limnonectes blythii of west Sumatra using Random Amplified Polymorphic DNA (RAPD). Materials and Methods: Thirty frogs were collected from three location of wildlife sanctuary in west Sumatra. Genetic variation analysis using RAPD with 11 OPA primer. The electrophoresis results were marked as 1 if a band founded and 0 if there's no band. Results: Genetic variation of three population were low and the highest founded on Malampah population, next on Sijunjung and lastly Harau . However, genetic differentiation inter-population was considered moderate, which of half of overall genetic variation generated from differentiation inter-population and also a half from differentiation of intra-population which supported by lower heterozygosity inter-population than intra-population heterozygosity. Gen flow value of inter-population was observed moderate. Conclusion: Genetic variation of L. blythii intra-population is lower than inter-population and the gene flow between L. blythii population considered moderate.

Key words: Limnonectes blythii, species genetic variation, wildlife sanctuary in west Sumatra, malampah population, heterozygosity, intra-population, inter-population

Citation: Wince Hendri, Djong Hon Tjong, Dahelmi and Dewi Imelda Roesma, 2019. Genetic variation of Limnonectes blythii (Anura: dicroglossidae) using RAPD (Random Amplified Polymorphic DNA) analysis in west Sumatra. Int. J. Zool. Res., 15: 1-5.

Corresponding Author: Djong Hon Tjong, Department of Biology, Faculty of Mathematics and Natural Sciences, Andalas University, Kampus Unand Limau Manis Padang 25163, West Sumatra, Indonesia

Copyright: @ 2019 Wince Hendri etal. This is an open access article distributed under the terms of the creative commons attribution License, which permits unrestricted use, distribution and reproduction in any medium, provided the original author and source are credited.

Competing Interest: The authors have declared that no competing interest exists.

Data Availability: All relevant data are within the paper and its supporting information files. 


\section{INTRODUCTION}

Bobo frog, Limnonectes blythii is one of widely spread species in southeast Asian, from Myanmar, Thailand, Peninsular Malaysia and northern Sumatra ${ }^{1-4}$. In west Sumatra, this frog population decline because of over harvest by local community for export commodity and their damaged habitat ${ }^{5}$.

This species status by IUCN ${ }^{6}$ is almost threatened. Some effort needed to conserve this species. However, there was some difficulties because no information provided for genetic variation of this species.

Research related to biology of L. blyhhii west Sumatra is still a few in number. One of the information of is biology, that is crucial for conservation is genetic variation. Genetic variation information of species are important to understand because the higher variation leads to the higher chances of a species ability to adapt in their environment ${ }^{7}$. The RAPD (Random Amplified Polymorphic DNA) can be used to analyze the genetic variation of frog ${ }^{8,9}$.

This research aimed to evaluate the genetic variation of L. blyrhii in west Sumatra using RAPD. The information obtained could be used to construct a future conservation plan for this frog species.

\section{MATERIALS AND METHODS}

Frogs collection locality: Thirty samples were collected from three location of wildlife sanctuary in west Sumatra i.e., Lembah Harau-Payakumbuh (Harau), Malampah-Pasaman Barat (Malampah) and Pangean II-Sijunjung (Pangean) and samples stored at Zoology Museum of Andalas University (Table 1, Fig. 1).

Table 1: Research sampling area of Limnonectes blythii

\begin{tabular}{|c|c|c|c|c|}
\hline Locations & Regency & Altitudes (m) & Coordinates & Number of samples \\
\hline Wildlife sanctuary of Lembah Harau-Payakumbuh & 50 Kota & $500-600$ & $0^{\circ} 04^{\prime} \mathrm{S}$ and $100^{\circ} 39^{\prime} \mathrm{E}$ & 10 \\
\hline Wildlife sanctuary of Malampah-Pasaman Barat & Pasaman Barat & $456-763$ & $0^{\circ} 11^{\prime} \mathrm{S}$ and $100^{\circ} 04^{\prime} \mathrm{E}$ & 10 \\
\hline Wildlife sanctuary of Pangean II-Sijunjung & Sijunjung & $300-600$ & $0^{\circ} 90^{\prime} \mathrm{S}$ and $101^{\circ} 50^{\prime} \mathrm{E}$ & 10 \\
\hline Total & & & & 30 \\
\hline
\end{tabular}

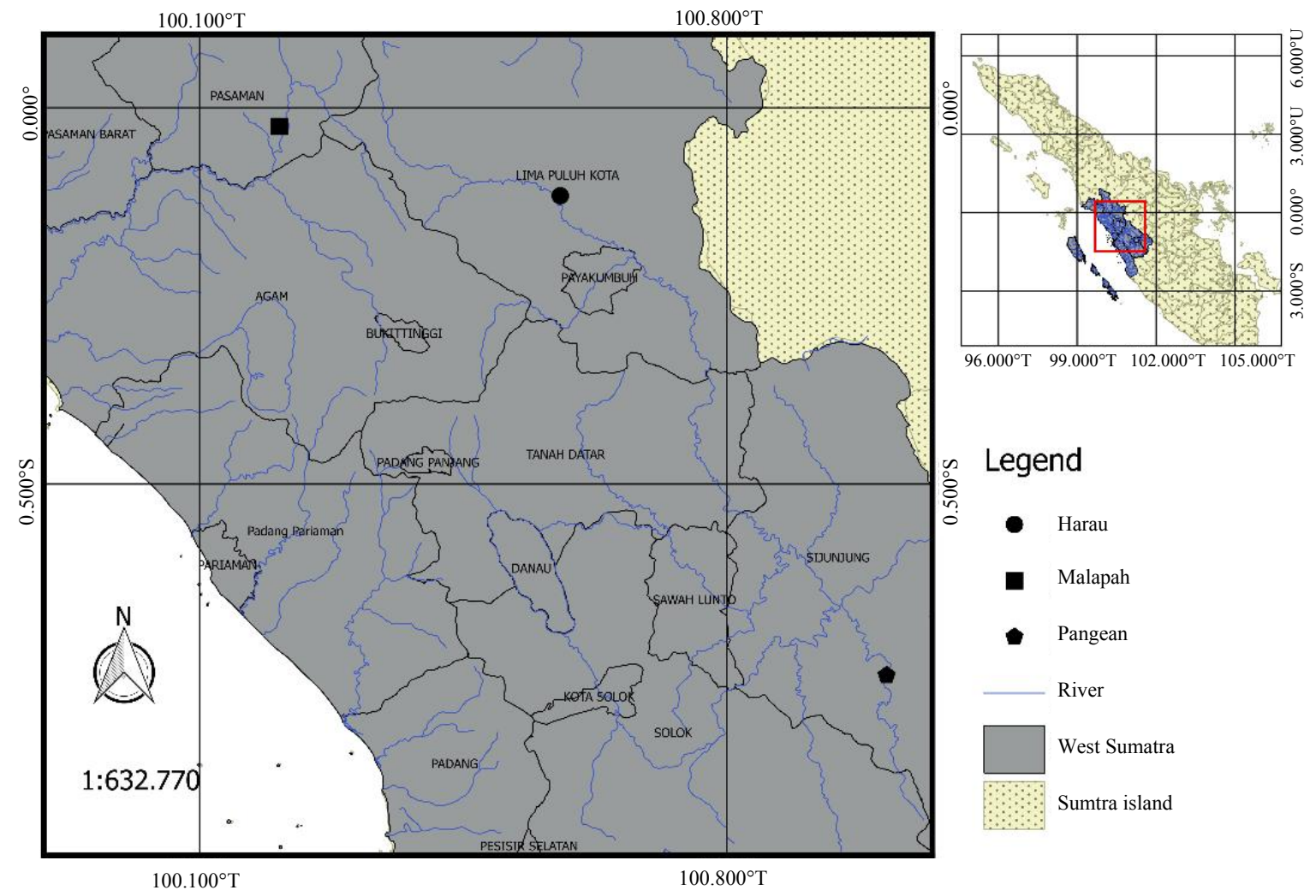

Fig. 1: Sampling location of Limnonectes blythii 
DNA isolation dan DNA primer: The DNA isolations were done using kit protocol of Roche, Blood and tissue Kit Roche. Eleven RAPD primer used were from Operon Technologies Inc., Alameda, USA, i.e., OPA-01, OPA-02, OPA-03, OPA-04, OPA-05, OPA-06, OPA-07, OPA-09, OPA-11, OPA-12 and OPA-13.

PCR amplification: Kit GoTaq Green 12,5 $\mu \mathrm{L}+9,5 \mu \mathrm{L}$ $\mathrm{ddH}_{2} \mathrm{O}+2 \mu \mathrm{L}$ DNA sample+1 $\mu \mathrm{L}$ primer used for DNA amplification. PCR cycle steps used were pre-denaturation at $94^{\circ} \mathrm{C}$ for $2 \mathrm{~min}$, denaturation at $94^{\circ} \mathrm{C}$ for a minute, annealing at $35^{\circ} \mathrm{C}$ for a minute and elongation at $72^{\circ} \mathrm{C}$ for $2,5 \mathrm{~min}$ and repeated for $45 \mathrm{cycle}^{10}$. The PCR results analysis then continued with gel electrophoresis using agarose $2 \%$ and colored with EtBr.

Data analysis: Bands of gel electrophoresis were analyzed by scoring based on the presence of DNA bands. Samples with DNA bands were mark as 1 and with no band founded mark as 0 . After that, the data analyzed using POPGENE version ${ }^{11} 1.31$, including population genetic variation (Percentage of polymorphic locus $(\mathrm{P})$, heterozygosity $(\mathrm{H})$, Shannon diversity (I)) and genetic variation inter-population (population heterozygosity $\left(H_{S}\right)$, heterozygosity intra-population $\left(D_{S T}\right)$, heterozygosity total $\left(H_{T}\right)$, genetic differentiation $\left(G_{S T}\right)$ and gen flow $(\mathrm{Nm})$.

\section{RESULTS}

Ninety five bands with size of 200-2.642 bp were founded, which consist of 82 polymorphic bands (85.77\%) and 13 DNA monomorphic bands (14.23\%) (Fig. 2).

The highest number of bands were founded from Malampah population (66 bands) and the lowest from Pangean population (42 bands). DNA bands resulted from each primers varies from 8-16 DNA bands and approximately 11.88 bands per primer. The highest numbers of polymorphic locus and percentage were found at Malampah population with 47 locus and $49.47 \%$ and Harau and Pangean population with 30 locus and $31.58 \%$ (Table 2).

Table 2 showed that highest number of heterozygosity found at Malampah population $(H=0.1602 \pm 0.020)$ followed by Pangean $(H=0.1274 \pm 0.020)$ and the lowest was Harau $(H=0.1263 \pm 0.019)$. Average Index Shannon (I) Harau population $(I=0.184 \pm 0.028)$, Pangean $(I=0.185 \pm 0.028)$ and Harau $(0.184 \pm 0.028)$.

Limnonectes blythii of west Sumatra Barat had lower population heterozygosity $\left(\mathrm{H}_{\mathrm{S}}=0.138\right)$ than heterozygosity inter-population $\left(D_{S T}=0.143\right)$, therefore the total population heterozygosity $\left(H_{T}=0.281\right)$. This results showed that genetic variety of $L$. blythii intra-population was smaller than inter-population. Inter-population genetic differentiation of L. blythii $\left(\mathrm{G}_{\mathrm{ST}}=0.5091\right)$ was considered moderate and gen
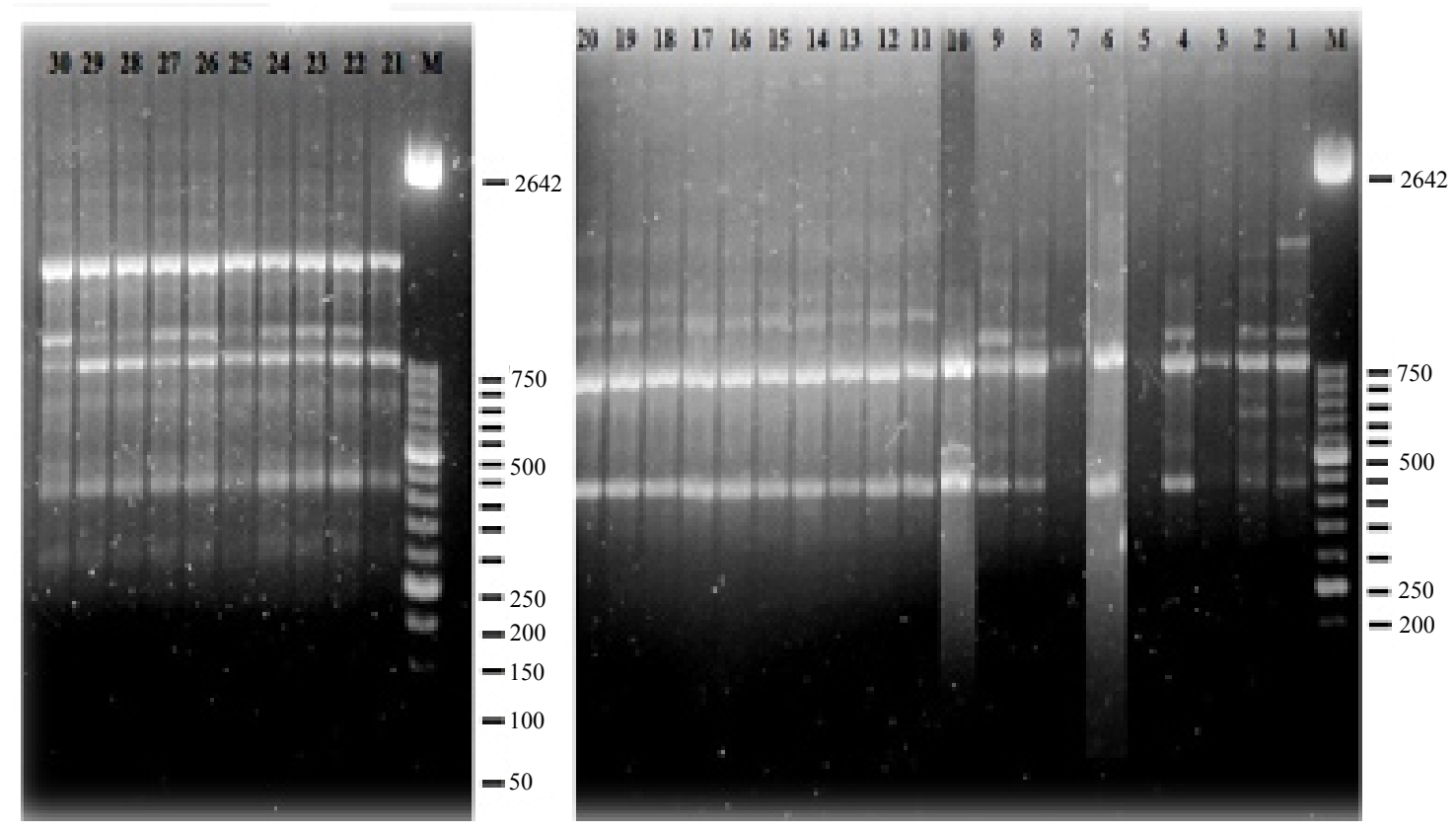

Fig. 2: DNA bands profile as the result of amplification using primer OPA-01 L. blythii on agarose gel 1.2\%. M: Marker of 100 bp, 1-10: Pangean population, 11-20: Harau population and 21-30: Malampah population 
Table 2: Genetic variation of L. blythiion west Sumatra

\begin{tabular}{llcc}
\hline & Populations & & \\
& - & & \\
Parameters & Lembah Harau-Payakumbuh & Malampah-Pasaman Barat & 42.00 \\
\hline Band number & 64.00 & 66.00 & 5.250 \\
Average bands & 8.00 & 8.250 & 30.00 \\
Polymorphic locus (N) & 30.00 & 47.00 & 31.580 \\
Polymorphic locus percentage (Pp) (\%) & 31.580 & 49.470 & $1.316 \pm 0.473$ \\
Number of allele observed (Na) & $1.326 \pm 0.467$ & $1.496 \pm 0.503$ & $1.230 \pm 0.371$ \\
Number of effective allele (Ne) & $1.225 \pm 0.362$ & $1.280 \pm 0.379$ & $0.127 \pm 0.020$ \\
Average Heterozygosity (H) & $0.126 \pm 0.019$ & $0.160 \pm 0.020$ & $0.185 \pm 0.028$ \\
Average Shannon index(l) & $0.184 \pm 0.028$ & $0.240 \pm 0.028$ & \\
\hline
\end{tabular}

Table 3: Genetic differentiation and gene flow of L. blythii on west Sumatra

\begin{tabular}{|c|c|c|c|c|c|}
\hline Samples number & $\mathrm{H}_{\mathrm{T}}$ & $\mathrm{H}_{\mathrm{S}}$ & $D_{\text {ST }}$ & $\mathrm{G}_{\mathrm{ST}}$ & $\mathrm{N}_{\mathrm{M}}$ \\
\hline 30 & 0.281 & 0.138 & 0.143 & 0.5091 & 0.4821 \\
\hline \multicolumn{6}{|c|}{$\mathrm{H}_{\mathrm{T}}:$ Total population heterozygosity $\left(\mathrm{H}_{\mathrm{S}}+\mathrm{D}_{\mathrm{ST}}\right)$} \\
\hline \multicolumn{6}{|c|}{$\mathrm{H}_{\mathrm{s}}$ : Heterozygosity intra-population } \\
\hline \multicolumn{6}{|c|}{$\mathrm{D}_{\text {ST }}$ : Heterozygosity inter-population } \\
\hline \multicolumn{6}{|c|}{$G_{S T}:$ Genetic differentiation inter-populasi } \\
\hline$N_{M}:$ Gen flow & & & & & \\
\hline
\end{tabular}

flow was $N_{M}$ (0.4821). Genetic differentiation showed that $50.91 \%$ of total genetic variation was inter-population and 49.09\% from intra-population as shown in Table 3.

\section{DISCUSSION}

Wildlife Sanctuary of Lembah Harau-Payakumbuh (Harau), Malampah-Pasaman Barat (Malampah) and Pangean II-Sijunjung (Pangean) are conservation area protected by Indonesian government. Outside sanctuary, Limnonectes blythii were rarely found. Higher genetic variety in Malampah population was most likely influenced by undisturbed river condition of this species habitat from human activities compared with Harau and Pangean. This species habitat in Harau was already disturbed by human activities for tourist attraction which lead to changes in vegetation and habitat destruction because of land fragmentation and pollution. Likewise with Pangean area, the river of L. blythii habitat is close with community settlement which caused pollution and habitat fragmentation. Limnonectes blythii used to live and reproduce at shallow and clear river flow in tropical forest ${ }^{12}$. Genetic variation of Hylarana parvicola on Malampah was higher than Pangean and Harau because both of the species habitat on already fragmented and polluted ${ }^{13}$. Anthropogenic factor greatly influence organism's habitat quality, including amphibians ${ }^{14}$.

Genetic variation on the three population were considered low with average heterozygosity between $0,160-0,126$. One of the reason behind this low genetic variety is intensive capture since 1970's until 2000's for trade and export goods. This condition leads to low possibility to find this species population outside conservation area. Small population would increase inbreeding and non-random mating thus decreasing genetic variation ${ }^{7}$. Small population also lower genetic mixing among individual in population that bring down genetic variation and fitness of that population ${ }^{15}$. The low genetic variation of $L$. blythii in north Thailand caused by captures for export ${ }^{16}$. Limnonectes blythii as one of the biggest frog species in the world and able to reach $90-260 \mathrm{~mm}$. The great size made this species often captured intensively and exported by local people for its legs for consumption ${ }^{5}$.

Genetic differentiation $\left(G_{S T}\right)$ and gen flow $\left(N_{M}\right)$ on all population in this research were considered moderate $G_{S T}$ (0.5091) and $N_{M}$ (0.4821). This result showed that genetic variation intra-population was lower than inter-population. Moderate inter-population genetic differentiation correlated with how this species living. The three population of this species live on different river habitat, which eliminate possibility to cross mating between populations. Higher probability of inbreeding inside population, lowering genetic variation and lead to moderate gen flow of three L. blythii populations. The number of gen flow shows the level of migration and dispersal between populations ${ }^{6}$. The that lower genetic differentiation and gen flow of $H$. parvacola population of west Sumatra caused by changes of vegetation types and microhabitat of their each population ${ }^{13}$.

Low genetic variation of three population observed from RAPD analysis implied that future sustainability of this species would be endangered. However, moderate genetic differentiation of L. blythii inter-population bring through the possibility to construct a conservation strategy. Another 
challenge to conserve frog species is how control human activities such as, land clearing for forestry, mining, expansion for residential areas and capture for trading, which lead to habitat deforestation, fragmentation and pollution. Damaged habitat cause L. blyhtii distribution obstructed and no migration occur. Inbreeding would increase and lead to decreasing genetic variation and species viability. Anthropogenic activities such as, urbanization, intensive agriculture are some of activities that damaged habitat structures and lead to forest fragmentation ${ }^{17}$. Anthropogenic activities have great influence to organism habitat quality, including amphibians ${ }^{14}$. Genetic variation determine organism ability to adapt for environmental changes ${ }^{18}$.

Based on low genetic variation of L. blythii in the west Sumatra both on inter and intra-population, in situ and ex situ conservation effort need to be planned involving collaboration between government, academics and community.

\section{CONCLUSION}

Present study concluded the genetic variation of L. blyhtii was mostly found at Malampah population and the lowest at Harau population. However, overall genetic variety from sampling sites were considered low. The intra-population genetic variety of $L$. blythii was lower than inter-population and genetic differentiation and gen flow of L.blythii inter-population were considered moderate.

\section{ACKNOWLEDGMENT}

Authors would like to send our thanks and gratitude to Directorate General of Higher Education for the research grant with contract number No. 18/KP/010/ KM/2016, February 22 nd, 2016. Express thanks also to BKDSA (Natural Resource Conservation Agency (BKSDA) West Sumatra by authors that had been permitted for collecting frog samples from conservation area protected by Indonesian government with the certificate number: SI.508/BKSDA Sumbar-1/2015 about Conservation Area Entrance Permit (SIMAKSI).

\section{REFERENCES}

1. Emerson, S.B., R.F. Inger and D. Iskandar, 2000. Molecular systematics and biogeography of the fanged frogs of Southeast Asia. Mol. Phylogenet. Evol., 16: 131-142.

2. Tjong, D.H., D.T. Iskandar and D. Gusman, 2010. Phylogentic relationship among Limnonectes (Ranidae: Amphibia) found in West Sumatra with other species from South East Asia based on the based on the 16S rRNA Gen. Makara J. Sci., 14: 79-87.
3. Inger, R.F. and D.T. Iskandar, 2005. A collection of amphibians from West Sumatra, with description of a new species of Megophrys(Amphibia: Anura). Raffles Bull.Zool., 53: 133-142.

4. Kurniawan, N., D.R. Ahmadlia, D.S. Nahari and A.S. Firdaus, 2015. Speciation and zoogeography of amphibian in sundaland. J. Biol. Res., 21: 1-7.

5. Iskandar, D.T. and W.R. Erdelen, 2006. Conservation of amphibians and reptiles in Indonesia: Issues and problems. Amphibian Reptile Conserv., 4: 60-87.

6. IUCN., 2018. IUCN red list of threatened species. International Union for Conservation of Nature (IUCN), Gland, Switzerland.

7. Allendorf, F.W. and G.H. Luikart, 2007. Conservation and the Genetics of Population. Blackwell Publishing, Malden, MA., USA., ISBN-13: 9781405121453, Pages: 664.

8. Trakimas, G., M. Matsui, K. Nishikawa and K. Kasugai, 2003. Allozyme variation among populations of Rana pirica (Amphibia: Anura). J. Zool. Syst. Evol. Res., 41: 73-79.

9. Zeisset, I. and T.J. Beebee, 2003. Population genetics of a successful invader: The marsh frog Rana ridibunda in Britain. Mol. Ecol., 12: 639-646.

10. Mendez, M.A., E.R. Soto, C. Correa, A. Veloso, E. Vergara, M. Sallaberry and P. Iturra, 2004. Morphological and genetic differentiation among Chilean populations of Bufo spinulosus (Anura: Bufonidae). Rev. Chilena Historia Nat., 77: 559-567.

11. Yeh, F.C., T. Boyle, R. Yang, Z. Ye and J.M. Xian, 1999. POPGENE version 1.31: A Microsoft window-based freeware for population genetic analysis. University of Alberta, Edmonton, Canada, August 1999.

12. Iskandar, D.T., 1998. Amfibi Jawa dan Bali. Puslitbang BiologiLIPI, Bogor, Indonesia, ISBN-13: 9789795790150 , Pages: 117.

13. Yuliatmy, P., D.I. Roesma and D.H. Tjong, 2016. Genetic variation of Rana parvaccola(Inger, Stuart and Iskandar, 2009) based on DNA microsatellites in West Sumatra. J. Entomol. Zool., 4: 1068-1071.

14. Spear, S.F. and A. Storfer, 2008. Landscape genetic structure of coastal tailed frogs (Ascaphus truel) in protected vs. managed forests. Mol. Ecol., 17: 4642-4656.

15. Phillipsen, I.C., 2011. Population genetics of Ranid frogs: Investigating effective population size and gene flow. Ph.D. Thesis, Oregon State University, Corvallis, OR., USA.

16. Suwannapoom, C., W. Wongkham, N. Sitasuwan, C. Phalaraksh and T. Kunpradid et al., 2012. Genetic Structure and Diversity of the Giant Frog (Limnonectes blythii) in Northern Thailand. Res. J. Applied Sci. Eng. Technol., 4: 2564-2568.

17. Johansson, M., C.R. Primmer, J. Sahlsten and J. Merila, 2005. The influence of landscape structure on occurrence, abundance and genetic diversity of the common frog, Rana temporaria. Global Change Biol., 11: 1664-1679.

18. Pertoldi, C., R. Bijlsma and V. Loeschcke, 2007. Conservation genetics in a globally changing environment: Present problems, paradoxes and future challenges. Biodivers. Conserv., 16: 4147-4163. 